\title{
THE MACDONALD CONSOLIDATED SCHOOL, AT GUELPH, ONTARIO
}

J. W. HOTSON, M.A.

Principal

There is nothing, it seems to me. that is of more vital importance in molding the destiny of a nation than its method of education in its rural districts. This is markedly true in the case of Ontario, where the majority of the population depends directly upon the soil for their livelihood. If education means anything, it should mean a preparation for real life; it should prepare men and women better to live, better to live among the surroundings in which they find themselves, better to battle with the problems of life that meet them on every side, so that they may become more and more part of their environment, and thus become contented and useful citizens. In order to be contented with their lot, humble though that lot may be, they must be interested in it. As a rule, a person is most interested in the things that he knows the most about. It is one of the chief aims of the Macdonald Consolidated School at Guelphand it should be of all rural schools-to engender such an interest and love for country life that the boys and girls will not be lured away by the attractions of the city.

I have great faith in the rural school, in its power to mold and build up a national character; but new educational methods must be used in order to secure the best results. In order to compete with our rivals in the world's markets, in order to equalize the advantages of country and city life, in order to make our country life attractive enough to keep our bright boys and girls on the farm, and thus maintain an intelligent, prosperous, progressive, and contented rural people, we must give immediate and effective attention to the needs of the rural school. A consolidated school makes it possible so to modify 
the curriculum that the development of the child is the ultimate aim, and not the cramming of the mind with mere facts.

In the Consolidated School at Guelph an attempt is being made "to adapt education to need." All the children who attend this school are country children; none from the city are accepted. The teachers are reminded, first, that they are dealing solely with rural children; second, that the majority of these children are going to spend their lives on the farm. Keeping these two facts in mind, an effort is made to adapt the teaching and what is taught to the special needs of the rural people.

The improvement of rural education is attempted along a line of what is taught. Besides the regular subjects, that are usually taught in the rural school, there are taught manual training, domestic science including sewing, nature-study, and school garden work. That phase of nature-study is emphasized that tends toward agriculture.

In Canada the greatest industry is essentially agriculture. Nearly 70 per cent. of its population live in rural districts and are dependent directly upon the farm for a livelihood, and their children are being educated in the rural school. There are about io per cent. of the population who are educated for the so-called "higher professions." Of these the greatest number come from the farm. When we reflect for a moment on the amount of money that is expended in the preparation of this Io per cent. for their life-work, we cannot help but feel disappointed, not that so much money is spent in their education, but that so little is expended in the preparation of the 70 per cent. who live in rural districts, to carry on scientifically and well the greatest of all industries-the cultivation of the soil.

In Ontario, as in many states of the Union, the educational system does not tend to produce the best results in the lives of the boys and girls of the country. The whole system tends to lead toward professional life rather than toward the farm. City things are being taught rather than country things. The farm and the farm home have been neglected; the greatest industry, farming, and the noblest institution, the farm home, have been discredited; and consequently the rural districts are being 
drained of their best young men and women. The present system of education does not prepare the rural children sufficiently for the life they are to live.

It is a mistaken idea that some people have that anyone can be a successful farmer. To be a successful farmer-that is, to make a profession of it-requires as much systematic training and careful experience as any other profession. The cause of so many failures in farm life is largely due to lack of early training along a line that would prepare them for this kind of work. Who is responsible for this lack of early training? If the rural people are to be so strong a factor in molding the character and destiny of the nation, does it not behoove every truly loyal citizen, whether he lives in a palatial dwelling or in the humblest cot in the land, to guard well the education of the rising generation?

Many of our rural people live in very humble circumstances. In many cases it is impossible for them ever to get away from these conditions. Why not lead them into a more sympathetic relation to their daily life by getting them interested in the numberless things around them in nature, and thus tend to make them more contented and better citizens?

It is one of the objects of the Macdonald Consolidated Rural School to teach the common things with which the child comes in contact every day, and in this way to lead him into a more sympathetic relation to his environment.

The Macdonald Consolidated School at Guelph is an experiment for the purpose of trying to improve rural education. It was established in the autumn of 1904, and is financed by Sir William Macdonald, of Montreal.

As Sir William's time is largely taken up with his business, the preliminary arrangements and inauguration of the enterprise were intrusted to Professor J. W. Robertson, LL.D., C.M.G., president of the Macdonald College of Agriculture at Ste. Anne de Bellevue, near Montreal. This school is situated on the grounds of the Ontario Agricultural College, Guelph, Ont., and is capable of holding 300 pupils. It is well furnished and equipped. To this school are brought all the children of 
school age in five surrounding school sections. These are brought in every morning, and taken out in the evening, in eight large, comfortable, covered vans. After the preliminary arrangements were made, the management of the school was vested in a local board, which consists of the three trustees from each of the sections being consolidated.

The rate of taxation is the same as it was before the inauguration of the scheme. All the additional expense is met by the Macdonald fund. This agreement lasts for three years, or until sufficient time has elapsed to give it a fair trial. At the end of that time the building and equipment will be handed over to the local board, and they may either continue the work or go back to the old district schools as they see fit. But it is firmly believed that the advantages of consolidation will be so great that they will not wish to return to the old system.

To show how the general public looks upon the work being done, another school section applied to be allowed to join the Consolidated School, and was admitted last August.

One of the great aims of this school is to interest the children, not only in country life, but in agricultural problems. The school garden has been found to be a potent factor in accomplishing this end. Every child in the school has a little plot of ground for himself, which is his very own. Here he is given instruction as to planting and caring for vegetables and flowers. The produce is his, and is either sold or taken home. Each class has a plot in which they work together. There are also some illustration plots in which the whole school works. These are for the purpose of experimenting with good and poor seeds, spraying, fertilizers, rotation of crops, etc.

Our point of view cannot be expressed better than in the words of Professor Bailey, of Cornell.

In the rural districts the school must become a social and intellectual center. It must stand in close relationship with the iife and activities of its community. It must not be an institution apart, exotic to the everyday lives; it must teach the common things, and put the pupil into sympathetic touch with his own environment. 